\title{
Artigo
}

\section{A arquitetônica habermasiana do Estado Democrático de Direito: uma proposta comunicativa de legitimidade democrática}

\author{
The architectural Habermas's democratic state: \\ a communicative proposal for democratic legitimacy
}

\section{Barbara Cristina Mota Johas}

Professora assistente nível I, do departamento de Ciência Política, Universidade Federal do Piaui (UFPI). Doutoranda no Programa de Pós-Graduação em Ciência Política pela Unicamp E-mail: <barbarajohas@yahoo.com.br>.

Resumo: $\bigcirc$ presente artigo tem como objetivo principal apresentar e analisar a articulação habermasiana dos conceitos de soberania popular e direitos humanos, a partir de uma perspectiva dialógica do processo de legitimação do Estado Democrático, com o intuito de demonstrar como Habermas traça um caminho que vai da desconstrução das interpretações correntes sobre estes conceitos até um processo de reconstrução dos mesmos em novas roupagens, permitindo uma "terceira via de interpretação" acerca das bases que fundamentam o Estado Democrático de Direito.

Palavras-chaves: Democracia; Autonomia; Direito; Habermas; Deliberação.

\begin{abstract}
This paper aims to present and analyze Habermas's articulation of concepts of popular sovereignty and human rights, from a dialogical perspective of the legitimacy of the democratic state process, in order to demonstrate how Habermas traces a path that will deconstruction of current interpretations of these concepts to a process of rebuilding these same concepts in new clothes, allowing a "third way of interpretation" about the bases underlying the democratic rule of law.
\end{abstract}

Keywords: Democracy; Autonomy; Right; Habermas; Deliberation.

A diferença entre a compreensão moderna de democracia e a noção clássica está relacionada à própria concepção de direito que, modernamente, se encontra dotada de três características principais: o direito moderno é positivo, cogente e estruturado individualisticamente, constituindo-se como o resultado de normas produzidas por um 
legislador político e sancionadas pelo Estado, tendo como principal objetivo a garantia das liberdades subjetivas. De acordo com Habermas, para uma corrente de interpretação liberal, a autodeterminação democrática somente se realiza pelo médium desses direitos - subjetivos - que asseguram estruturalmente as liberdades. Portanto, a noção de um domínio da lei (rule oflaw), que se expressa na ideia de direitos humanos e de soberania popular, passa a ser compreendida como uma segunda fonte de legitimidade. Neste ponto, apresenta-se para Habermas uma problemática que deve ser discutida: a relação entre o princípio democrático e o Estado de Direito. Na visão clássica, as leis são a expressão da vontade ilimitada de cidadãos reunidos.

[...] não importa o modo como o ethos da forma de vida política comum se espelha nas leis: esse ethos não constitui uma limitação, na medida em que obtém validade através do processo de formação da vontade dos cidadãos, ao passo que o princípio do exercício do poder no Estado de direito parece colocar limites à autodeterminação soberana do povo, pois o "poder das leis" exige que a formação democrática da vontade não se coloque contra os direitos humanos positivados na forma de direitos fundamentais. Ora, na história da filosofia política, as duas fontes de legitimação do Estado democrático de direito surgem, concorrendo uma contra a outra. (HABERMAS, 2003a, p. 153-154)

Será desses embates que surgirão questões sobre qual tipo mais correto de liberdade deve ser compreendido como fonte última da legitimação do Estado; a dicotomia, já clássica na ciência política, entre liberdade dos modernos vs. liberdade dos antigos. Segundo Habermas, o problema principal a ser levantado é o seguinte: "[...] o que deve vir antes: os direitos subjetivos de liberdade dos cidadãos da sociedade econômica moderna ou os direitos de participação política dos cidadãos democráticos?". (HABERMAS, 2003a, p. 154-155) Para o teórico alemão, boa parte dos pesquisadores compreende que a autonomia privada dos cidadãos assume sua forma no núcleo dos direitos fundamentais; em oposição, podemos encontrar interpretações que veem na autonomia política dos cidadãos a incorporação da auto-organização de uma comunidade que cria as suas próprias leis. Em suma, a partir dessas interpretações, ocorre uma hierarquização entre o princípio dos direitos humanos e a soberania popular, de modo que, em cada uma das interpretações, a legitimidade democrática reside em um dos polos tidos como antagônicos. 
Por isso, a muitos parece que a fundamentação normativa do Estado democrático de direito pressupõe o estabelecimento de uma hierarquia entre o princípio dos direitos humanos e o da soberania popular: ou as leis, inclusive a lei fundamental, são legítimas, quando coincidem com os direitos humanos, independentemente da origem e do fundamento de sua legitimidade, e, nesse caso, o legislador democrático poderia decidir soberanamente, sem se preocupar com os prejuízos que daí adviriam para o princípio da soberania do povo; ou as leis, inclusive a lei fundamental, são legítimas quando surgem da formação democrática da vontade. E, neste caso, o legislador democrático poderia criar uma constituição arbitrária que iria ferir a própria lei fundamental, o que constituiria um prejuízo para a ideia do Estado de direito. (HABERMAS, 2003, p. 154)

Entretanto, para Habermas, tais posições encontram-se na contramão de uma interpretação muito forte; em seu entender, a perspectiva dos direitos humanos, transformada em direitos fundamentais, não pode ser externamente obrigatória ao legislador soberano, como uma espécie de limitação, nem tampouco pode ser utilizada de maneira instrumental, como um elemento funcional voltado para um determinado fim. Por conseguinte, esses princípios, usualmente tidos como dicotômicos, podem ser entendidos como constituindo duas faces de uma mesma estrutura, ou seja, soberania popular e direitos humanos compõem dois momentos interdependentes de um mesmo processo, a saber: a formação do Estado democrático de direito. De acordo com Habermas, essa cooriginariedade pode ser compreendida também a partir da perspectiva das autonomias público/privada, na medida em que são conceitos interdependentes, com base em sua implicação material.

Para fazerem um uso adequado de sua autonomia pública, garantida através de direitos políticos, os cidadãos tem que ser suficientemente independentes na configuração de sua vida privada, assegurada simetricamente. Porém, os "cidadãos da sociedade" (Gesellschaftsbürger) só podem gozar simetricamente de sua autonomia privada, se, enquanto cidadãos do Estado (Staatsbürger), fizerem uso adequado de sua autonomia política - uma vez que as liberdades de ação subjetivas, igualmente distribuídas, têm para eles o "mesmo valor". (HABERMAS, 2003, p. 155)

Para a visão habermasiana, foram Kant e Rousseau os responsáveis por transformar a intuição dessa correlação no próprio conceito de autonomia; contudo, é importante destacar que a noção de autonomia que possibilita que cada cidadão se entenda como autor e endereçado do direito, não Ihe atribui uma "carta de alforria voluntarista", 
permitindo a tomada de qualquer decisão arbitrária, uma vez que a garantia de ação livre, no espaço das leis, é o núcleo da autonomia privada e não da autonomia pública. Para Habermas:

Na base dessa liberdade de arbítrio, atribui-se aos cidadãos a autonomia no sentido de uma formação racional da vontade - mesmo que ela não possa ser exigida legalmente. Eles devem ligar a sua vontade àquelas leis que eles se dão a si mesmos em consequência de uma vontade comum, obtida através de um discurso, pois a ideia de autolegislação, quando bem entendida, estabelece um nexo interno entre razão e vontade, uma vez que a liberdade de todos passa a depender da consideração simétrica da liberdade individual de cada um, que pode tomar posição dizendo sim ou não, e, sob esta condição, só encontram assentimento racional as leis que são do interesse simétrico de cada um. (HABERMAS, 2003a, p. 155-156)

Com Locke, Rousseau e Kant, estabeleceu-se um conceito de direito que se espera que dê conta tanto da legitimidade quanto do caráter coercitivo do direito como assegurador da liberdade. Devido ao aspecto modificável das normas, haja vista que foram feitas por legisladores políticos, emerge, nessas circunstâncias, uma exigência de legitimação, segundo a qual esse direito deve assegurar igualmente a autonomia de todos os cidadãos. Para que tal exigência possa ser atendida, Habermas argumenta que o procedimentalismo democrático legislativo apresenta-se como suficiente, porque cria uma interdependência conceitual entre o caráter coercitivo e a modificabilidade do direito positivo, de um lado, e um modo de estabelecimento do direito capaz de gerar legitimidade, por outro. Desse modo, de um ponto de vista normativo, existe não apenas uma relação historicamente casual entre a teoria do direito e a teoria da democracia, mas sim uma relação conceitual ou interna entre ambas. (cf. HABERMAS, 2002, p. 294-95)

Essa relação interna encontra-se extremamente fundada nas pressuposições de nossa ação jurídica cotidiana, pois, na forma de validação do direito, o aspecto da sua facticidade de imposição por via estatal se junta à força legitimadora do procedimento formador desse direto, o qual é racional justamente por fundamentar a liberdade. Kant, ao defender seu conceito de legalidade, já salientava a ligação entre esses dois modelos, sem os quais não é possível exigir conformidade de uma ação à lei. "Normas jurídicas tem de ser tais que possam ser consideradas de um só tempo, e sob cada um dos diferentes aspectos, como leis coercitivas e como leis de liberdade". (HABERMAS, 2002, p. 295) 
De acordo com Habermas, segundo o próprio Kant, legalidade e moralidade são elementos distintos, visto que às possibilidades de conformidade ou desconformidade de uma determinada ação com relação à lei, sem referências aos motivos da ação, dá-se o nome de legalidade, enquanto, porém, as noções de dever ligadas à lei e que, ao mesmo tempo, formam o móvel da ação constituem a moralidade propriamente dita, portanto, para Kant.

Uma vez que a pergunta acerca da legitimidade das leis que garantem a liberdade precisa encontrar uma resposta no interior do direito positivo, o contato da sociedade faz prevalecer o princípio do direito, na medida em que liga a formação política da vontade do legislador a condições de um procedimento democrático, sob os quais os resultados que aparecem, de acordo com o procedimento, expressam per se a vontade consensual ou o consenso racional de todos os participantes. Desta maneira, no contrato da sociedade, o direito dos homens a iguais liberdades subjetivas, fundamentado moralmente, interliga-se com o princípio da soberania do povo. (HABERMAS, 1997, Tomo I, p. 127)

Habermas, em sua compreensão de direito moderno, também compartilha essa perspectiva, de sorte que, segundo o teórico, a validade de uma norma jurídica é concebida como um equivalente explicativo de um aspecto muito singular do Estado, qual seja, o de garantir de forma simultânea a imposição jurídica efetiva, enquanto um procedimento de conformidade relativa das normas passíveis de sanção, e a instituição legítima do direito que se acredite possa tornar passível de efetivação uma observância das normas por respeito às leis.

Contudo, para Habermas, na arquitetônica kantiana não fica claro como estes dois princípios se comportam: o conceito de autonomia, responsável pela sustentação de toda a estrutura teórica, é introduzido a partir da perspectiva privada daqueles que julgam moralmente; porém, o conceito de autonomia é explicado na forma legal do imperativo categórico, em suma, em uma legislação pública realizada democraticamente. Desta forma, o princípio jurídico em Kant não requer apenas o direito a liberdades subjetivas em geral, mas também iguais liberdades subjetivas, ou seja, a compatibilidade entre a liberdade de cada um com a liberdade de todos os outros, segundo uma lei geral, e somente a partir destas discussões pode entrar em jogo a pretensão de legitimidade do próprio direito positivo. 
Em Kant, o princípio do direito carrega o peso da legitimação enquanto imperativo categórico sempre presente como máxima de universalização. Desta construção resulta, para Habermas, uma subordinação do direito à moral, na medida em que, em última instância, ao direito cabe apenas garantir as liberdades subjetivas de ação por meio da restrição fática: sua função, enquanto elemento de integração social, desaparece. Para a ótica habermasiana, tal subordinação é incompatível com uma perspectiva na qual a autonomia se realiza no médium do próprio direito. O conceito de autolegislação requer que os civis submetidos às leis se entendam também como autores do direito. Para tanto, não é suficiente considerar os direitos fundamentais como direitos moralmente fundados: somente a construção politicamente autônoma do direito permite que seus destinatários compreendam a ordem jurídica em geral, "a ideia de autolegislação de cidadãos não pode, pois, ser deduzida da autolegislação moral de pessoas singulares". (HABERMAS, 1997, Tomo I, p. 158) Para o teórico alemão, a autonomia deve ser entendida em uma perspectiva mais neutra; para tanto, introduz o princípio do discurso, que é indiferente com relação tanto à moral quanto ao direito. Tal princípio deve assumir a "figura de um princípio de democracia, o qual passa a conferir força legitimadora ao processo de normatização". (HABERMAS, 1997, Tomo I, p. 158)

Os conceitos "princípio moral" e "princípio da democracia" estão interligados; tal circunstância é encoberta pela arquitetônica da doutrina do direito. Se isso for correto, o princípio do direito não constitui um membro intermediário entre princípio moral e princípio da democracia. No meu entender, a falta de clareza sobre a relação entre estes três princípios deve ser lançada na conta de Kant e de Rousseau, pois, em ambos, existe uma não confessada relação de concorrência entre os direitos humanos, fundamentados moralmente, e o princípio da soberania do povo. (HABERMAS, 1997, Tomo l, p. 128)

Habermas refuta as explicações que buscam vincular o direito ao seu aspecto moral como alternativa possível para a questão do eterno retrocesso legislativo a que o direito poderia estar submetido, considerando a necessidade de constante legitimação em modelos democráticos. Isto se deve, para ele, não apenas ao fato de as imagens de mundo monolíticas terem sido desfeitas na sociedade plural, assim como as éticas vinculativas, mas, sobretudo, ao fato de o direito moderno, em razão de seu formalismo 
característico, isentar-se de qualquer tentativa de intervenção fruto de uma consciência moral pós-tradicional. (cf. HABERMAS, 2002, p. 295-96)

\section{Soberania popular e Estado de Direito - Autonomia privada e autonomia pública: uma relação complementar}

O direito subjetivo, componente estrutural das ordens jurídicas modernas, tem o importante papel, dentro das sociedades pós-convencionais, de desonerar os indivíduos do direito com relação a preceitos morais. As garantias de espaços autônomos de ação para agentes que se guiam a partir de suas próprias preferências e sem impedimentos, para além das restrições legais, trazem consigo uma clara delimitação entre o espaço das liberdades negativas e o campo propriamente moral, no qual existe uma forte simetria entre direitos e deveres; as obrigações jurídicas constituem o resultado lógico da atribuição de direitos dentro da moral. Esse processo de exaltação dos direitos em relação aos deveres pode ser entendido através da diferenciação entre os conceitos de pessoa do direito e de comunidade jurídica. De acordo com Habermas, o universo moral ilimitado estende-se sobre todas as pessoas existentes, e a própria moral estende-se até a proteção da pessoa individualizada; em consequência, a comunidade jurídica protege a integridade de seus membros exatamente na mesma medida em que estes assumem o status, artificialmente criado, de portadores de direitos subjetivos. Ocorre, portanto, uma relação de complementaridade entre direito e moral mais do que, propriamente, de subordinação. (cf. HABERMAS, 2002, p. 296-297)

Questões morais não são o único campo de atuação das regulamentações jurídicas, mas também dizem respeito às questões pragmáticas e éticas. Diferentemente das reivindicações normativas para validação de preceitos morais, que são essencialmente delimitadas, as reivindicações de legitimidade das regulamentações jurídicas possuem como base razões de diferentes tipos, sendo dependentes de canais discursivos e de negociação que se entrelaçam, e não apenas de discursos estruturados moralmente.

Pode-se entender o direito de uma maneira muito mais adequada do que como um complemento funcional da moral. Pois o direito positivamente válido, legitimamente firmado e cobrável através de ação judicial, pode tirar das pessoas que agem e julgam moralmente o peso das grandes exigências cognitivas, motivacionais 
e organizacionais que uma moral ajustada segundo a consciência subjetiva acaba impondo a elas. O direito pode compensar as fraquezas de uma moral exigente que, se bem analisada suas consequências empíricas, não proporciona senão resultados cognitivamente indefinidos e motivacionalmente pouco seguros. (HABERMAS, p. 2002, 297)

Segundo Habermas, tais regulamentações contêm em seu bojo uma dimensão concreta que impede que estas se legitimem apenas por meio da consonância de tais regulamentações com princípios morais. Dessa forma, o direito positivo precisa buscar sua fonte de legitimidade na igual proteção da liberdade de seus membros. Ainda no campo das discussões acerca da autonomia, Habermas argumenta que o sentido kantiano de autonomia refere-se a um processo no qual cada indivíduo segue as normas por ele mesmo outorgadas, ou seja, possui um duplo papel enquanto autor e endereçado do direito, ponto de vista para o qual a autonomia que se desenvolve sob as bases morais possui um sentido monolítico, diferentemente da autonomia exercida no campo do direito, marcada por uma duplicidade - autonomia privada e pública - que necessita de um elemento intermediador para assegurar a preservação de ambas.

As liberdades de ação individuais do sujeito privado e a autonomia pública do cidadão ligado ao Estado possibilitam-se reciprocamente. É a serviço dessa convicção que se põe a ideia de que as pessoas do direito só podem ser autônomas à medida que the seja permitido, no exercício de seus direitos civis, compreender-se como autores dos direitos aos quais devem prestar obediência, e justamente deles. (HABERMAS, 2002, p. 298)

Para Habermas, nem Kant nem Rousseau utilizaram o conceito de autonomia para fundamentar a democracia em termos de um Estado de Direito. O último atribuiu racionalidade à vontade do povo, ligando o processo democrático à forma de leis gerais e abstratas, enquanto o primeiro buscou o mesmo objetivo, através da subordinação do direito à moral. Habermas procura demonstrar que esse nexo interno entre razão e vontade somente pode se desenvolver, na dimensão do tempo, por meio de um processo histórico que se corrige a si próprio. De acordo com o autor, a aparente dissonância entre Estado de Direito e democracia pode ser diluída na própria história, quando entendemos a Constituição como um processo que torna o ato fundador constituinte 
ininterrupto, no interior do caminho evolutivo das gerações posteriores. (cf. HABERMAS, 2003, p. 156)

De acordo com Habermas, em países onde existe uma instituição independente para examinar a constitucionalidade das leis emitidas pelo congresso, há uma discussão mais constante acerca da relação entre Estado de Direito e democracia, tais como os Estado Unidos e a Alemanha'. Nesse ponto das discussões, torna-se importante abordar a seguinte questão: será que a dimensão da revisão judicial pode ser considerada elemento-chave para compreender a relação entre soberania do povo e Estado de Direito? Na compreensão de Habermas, autores como William J. Brennan entendem o papel do juiz a partir de uma perspectiva na qual este é tomado como um intérprete da Constituição, livre de suspeitas, haja visto que suas decisões somente são possíveis por um processo no qual as vozes conturbadas da sociedade civil e do espaço público, como um todo, são ouvidas. Nessa compreensão, a interação com a sociedade civil deve colaborar para legitimar democraticamente as ações de um juiz, que, do ponto de vista propriamente democrático, não é suficientemente legitimado, "pois o alargamento da base de decisão faz com que o tribunal, que continua a decidir de modo independente, amplie também o campo de visão dos especialistas". (HABERMAS, 2003, p. 158)

Para Habermas, as considerações acerca das possibilidades de contribuição dessa perspectiva para a resolução desse suposto paradoxo precisam ser avaliadas de uma forma mais detalhada, especialmente aquelas sobre o real papel de um discurso público veemente quanto às práticas de decisão no tribunal, assim como ao papel legitimador dessa relação. Habermas acrescenta:

Temo, porém, que razões pragmáticas e circunstâncias históricas são muito mais decisivas, quando se trata de saber o modo como a tarefa de controlar as nor-

\footnotetext{
"Nos Estados Unidos, desde há muito tempo, se desenvolve um debate acalorado sobre a legitimidade do controle de normas (judicial review), exercido pela Supreme Court em última instância, pois a convicção republicana, segundo a qual 'todo o poder do Estado vem do povo', recusa-se a aceitar o poder elitista de especialistas em direito, que, apelando somente para sua competência específica de interpretar a constituição e sem serem legitimados pelas maiorias democráticas, revogam decisões de um legislativo eleito democraticamente". (Habermas, 2003, p. 157) Essas discussões também podem ser vistas em teóricos que debatem as estruturas do federalismo, em especial o norte-americano, na discussão mais específica sobre as estruturas institucionais que restringem ou não o poder do demos. Sobre o conceito de demos constraining, em especial, ver teóricos como Alfred Stepan. In: "Toward a New Comparative Analysis of Democracy and Federalism: Demos Constraining and Demos Enabling Federations" (1999); e Willian H. Riker. In: "Implications for the Disequilibrium of Majority Rule for the Study of Institutions" (1980). American Political Science Review, vol. 74, p. 432-447.
} 
mas, num dado contexto, deve ser organizada. Como sabemos, tais possibilidades de institucionalização têm que ser avaliadas à luz dos princípios da soberania popular e do Estado de direito, porém a constelação e o jogo desses princípios não propiciam soluções capazes de satisfazer a todos. (HABERMAS, 2003, p. 158)

Assim, Habermas argumenta que o caminho traçado por certas correntes teóricas carece de uma visão menos dicotômica e mais intersubjetiva entre a construção da autonomia privada e da autonomia pública. Na proposta liberal, encontramos uma posição que concebe o processo democrático como dependente de uma estrutura jurídica institucionalizada, de modo que a lei fundamental é considerada como pré-requisito básico para a construção de todo o modelo democrático: "a relação entre a democracia, como fonte da legitimação, e um Estado de Direito, que não necessita de legitimação, não é paradoxal, pois as regras constitutivas que tornam possível uma democracia não podem limitar a prática democrática através de normas impostas a partir de fora". (HABERMAS, 2003, p. 159)

Para o teórico em questão, os direitos fundamentais liberais, justamente por se constituírem primordialmente das liberdades liberais clássicas - liberdade religiosa, liberdade de propriedade, liberdade de expressão, entre outras -, têm como principal tarefa possibilitar a formação de indivíduos autodeterminados e, por conseguinte, não podem ser compreendidos como um meio pelo qual os direitos políticos de formação democrática das opiniões e vontades são formados, enfatizando que "o fato de os direitos fundamentais liberais tornarem possível a democracia não basta para demonstrar que eles tornam viável a democracia - o que, no entanto, seria suficiente para os direitos fundamentais políticos". (HABERMAS, 2003, p. 160)

O liberalismo teve como um dos seus objetivos principais denunciar os possíveis perigos que advêm de uma concepção de democracia baseada nas maiorias. Enfrentando as possibilidades de uma maioria tornar-se tirânica em relação aos indivíduos, o liberalismo procurou ressaltar a precedência dos direitos humanos com relação à vontade do povo, garantindo assim uma "defesa" jurídica aos indivíduos, contra essas maiorias. O Estado, como aparato administrativo, tem por finalidade permitir o máximo de liberdade para cada cidadão, defender os direitos dos indivíduos, assim como de agregar e administrar os interesses privados e conflitantes, a fim de garantir o interesse coletivo. O poder público, para os pensadores liberais, deve possuir um âmbito restrito 
de atuação, com o intuito de não permitir que, com o excesso de poder, o Estado se torne autoritário. (cf. HABERMAS, 1995, p. 39).

Para Habermas, na concepção liberal, o cidadão é entendido a partir dos direitos subjetivos que possui perante o Estado e os demais indivíduos. No tocante aos direitos políticos, estes consistem na possibilidade de cada cidadão fazer valer os seus interesses particulares, "ao permitir que esses interesses possam agregar-se (por meio de eleições e da composição do parlamento e do governo) com outros interesses privados até que forme uma vontade política capaz de exercer uma efetiva influência sobre a 'administração'". (HABERMAS, 1997, p. 40-41)

Outra interpretação possível sobre essa relação é aquela fornecida pelo republicanismo, para o qual a Constituição deve ser fruto de um processo inclusivo de formação da opinião e da vontade dos cidadãos, dado que, de outra forma, ela entraria em conflito com a soberania popular; nesse caso, a autodeterminação teria de ser compreendida como autoentendimento político/ético, fruto de um processo livre de coação em que os cidadãos são acostumados a ser livres. O republicanismo sempre concedeu uma primazia à soberania popular, isto é, à autonomia pública dos cidadãos, em detrimento da autonomia privada. Segundo Habermas, nessa teoria, a política é compreendida como um elemento constitutivo do processo de formação da própria sociedade: a política se constituiria como o meio pelo qual os indivíduos, dentro da sociedade, tomam consciência de sua interdependência, transformando suas relações numa associação entre indivíduos livres e portadores de direitos iguais. (cf. HABERMAS, 1995, p. 39-40) Por essa concepção, sociedade civil, tomada como infraestrutura, espaço público e político adquirem um significado estratégico, dado que têm como função propiciar a integração entre a autonomia dos cidadãos. $\mathrm{O}$ poder político provém, assim, na interpretação de Habermas, de um poder comunicativamente gerado dentro da prática da autodeterminação, legitimando-se por meio da institucionalização das liberdades públicas. (HABERMAS, 2002, p. 279-89)

O Estado tem como justificação de sua existência a garantia de um processo que possibilita a formação da opinião e da vontade política do cidadão livre sobre os fins e normas que dizem respeito ao interesse comum. Dessa maneira, espera-se que os indivíduos tomem suas decisões políticas tendo por base interesses privados e coletivos. A concepção republicana vê no direito a ordem jurídica objetiva, que, ao mesmo tempo, 
garante a integridade da comunidade e o direito de autonomia ao indivíduo. Os direitos, em última instância, não passam de determinações da vontade política. A comunidade, por sua vez, tem como objetivo o bem comum, que consiste no sucesso do estabelecimento do conjunto de direitos que melhor se aplicam a uma determinada sociedade, concebendo-se aqui a política enquanto um processo de argumentação racional que está orientado para a aplicação de uma ordem justa, tendo em vista regular as relações sociais. (cf. HABERMAS, 2002, p. 281-283) Nesse sentido, há uma separação entre o poder comunicativo, derivado da comunicação política, e o poder administrativo, sendo que o primeiro, por meio do exercício contínuo das discussões políticas, exerce controle sobre o modo de exercício do segundo.

Sob esta condição, os princípios do Estado de direito não seriam prejudicados, pois seriam reconhecidos como parte integrante de um ethos democrático. Eles estariam enraizados de modo muito mais duradouro e livre, nos motivos e sentimentos dos cidadãos, do que no caso de uma imunização jurídica formal contra a vontade de maiorias tirânicas que pretendem modificar a constituição. Todavia, essa consideração cai num petitio principii, pois introduz, na história das mentalidades e na cultura política da comunidade, as orientações valorativas liberais que tornam supérflua a imposição do direito através de costumes e da autoligação moral. (HABERMAS, 2003, p. 160)

Contudo, a interpretação republicana pode receber um sentido procedimental, quando a consideração racional da formação democrática da opinião e da vontade, autolimitativa, é deslocada das fontes de um consenso valorativo para formas características do processo democrático. Procedendo desse modo, a Constituição passa a possuir um sentido procedimental capaz de produzir canais de comunicação responsáveis pela existência e permanência do uso público da razão e das compensações entre interesses divergentes. "Dado que esse conjunto de condições viabilizadoras tem que ser efetuado no médium do direito, elas se estendem [...] tanto aos direitos liberais de liberdade, como aos direitos políticos de participação". (HABERMAS, 2003a, p. 161)

Segundo Habermas, não há dúvidas de que a teoria política até o momento não logrou equacionar de modo sério a tensão entre a soberania popular e os direitos humanos. As duas grandes abordagens teóricas presentes na teoria política: o republicanismo - que remonta a Aristóteles e ao Humanismo cívico - e o liberalismo - que remonta a Locke - não conseguiram equilibrar a tensão existente entre esses dois elementos, 
direitos humanos e soberania popular, devido mesmo à sua forma de abordar essa relação. Ou seja, para Habermas, a ênfase unilateral em um dos elementos da equação levou a uma perspectiva equivocada, que compreende tal relação de uma forma hierárquica, levando cada uma dessas correntes a ver-se "obrigada" a dar primazia a um dos elementos, no processo de constituição da estrutura teórica. (cf. HABERMAS, 2001, p. 146/147)

Em um caso, os direitos humanos deveriam a sua legitimidade ao resultado da autocompreensão ética e da autodeterminação soberana de uma coletividade política; no outro caso, eles deveriam construir limites legítimos, a partir deles mesmos, que vedassem à vontade soberana do povo a usurpação das esferas de liberdade subjetivas intocáveis. Contra esses unilateralismos complementares deve-se perseverar no fato de que a ideia dos direitos humanos - o direito fundamental kantiano sobre as mesmas liberdades subjetivas de ação - nem se impõe simplesmente ao legislador soberano como um limite externo, nem deve ser instrumentalizada como um requisito funcional para seus objetivos. (HABERMAS, 2001, p. 147)

Dessa maneira, é fácil entender por que as teorias do direito racional construíram duas respostas para as questões sobre a legitimação dessa estrutura. A soberania popular, de um lado, se expressa nos direitos à comunicação e participação, assegurando a autonomia pública dos cidadãos. De outro lado, o domínio das leis garantido pelos direitos humanos está fundamentado nos direitos clássicos liberais, que permitem o desenvolvimento da autonomia privada de membros da sociedade civil. Fixados tais pontos de vista, o direito legitima-se como o meio garantidor igualmente das autonomias privada e pública. Apesar dessa articulação efetuada pelo direito, a filosofia não tem levado a sério a tarefa de dissolver a tensão entre tais elementos, ou seja " entre o dilema liberdade dos antigos vs. liberdade dos modernos.

Para Habermas, as interpretações sobre a relação entre as duas faces da autonomia não têm conseguido operacionalizar a equiprimordialidade dessa relação, atribuindo sempre uma ênfase maior a algum dos elementos da equação. Para que essa interdependência possa receber a expressão merecida, ele argumenta que é necessário considerar "o procedimento democrático a partir de pontos de vista da teoria do discurso". (HABERMAS, 2002, p. 299-300) Devido à própria configuração da sociedade moderna, marcada pelo pluralismo de visões de mundo, o processo democrático é o que pode fornecer a base legitimadora para o processo de construção legal, a partir de uma 
perspectiva procedimental discursiva, que integra de maneira equiprimordial direitos humanos, enquanto possibilitadores da práxis de autodeterminação, e soberania popular, enquanto elemento legitimador do próprio processo.

Regulamentações que podem requerer legitimidade são justamente as que podem contar com a concordância de possivelmente todos os envolvidos como participantes em discursos racionais. Se são discursos e negociações - cuja justeza e honestidade encontram fundamento em procedimentos discursivamente embasados -, o que constitui o espaço em que se pode formar uma vontade política racional, então a suposição de racionalidade que deve embasar o processo democrático tem necessariamente de se apoiar em um arranjo comunicativo muito engenhoso: tudo depende das condições sob as quais se podem institucionalizar juridicamente as formas de comunicação necessárias para a criação legítima do direito. A almejada coesão interna entre direitos humanos e soberania popular consiste assim em que a existência de institucionalizações jurídicas de uma prática civil do uso público das liberdades comunicativas seja cumprida justamente por meio dos direitos humanos. Direitos humanos que possibilitam o exercício da soberania popular não se podem impingir de fora como uma restrição. (HABERMAS, 2002, p. 300)

Não há dúvidas quanto à firme fundamentação que os direitos humanos possuem, do ponto de vista moral; o que, porém, é importante ressaltar é a necessidade de atentar para o fato de que a dimensão moral não pode ser concebida, nem tampouco empregada, como base única para a construção do direito, uma vez que a própria ideia de autonomia jurídica do cidadão requer que este participe como coautor desse código legal. Todavia, esses cidadãos já não possuem mais a livre escolha dos meios pelos quais podem efetivar sua autonomia, em suma, "a ideia de autolegislação democrática não tem opção senão validar-se a si mesma no médium do direito". (HABERMAS, 2000, p. 301) Entretanto, para institucionalizar os pressupostos comunicativos necessários ao processo de coautoria na formação legislativa, ou seja, a garantia dos direitos políticos, é preciso que a autonomia privada dos sujeitos do direito esteja assegurada. Se os direitos fundamentais, responsáveis pela garantia da autonomia privada, não forem assegurados, não é possível a existência do médium, pelo qual se institucionalizam juridicamente as condições de desenvolvimento da autonomia pública e, portanto, do cidadão do Estado, o que leva à compreensão da equiprimordialidade existente entre soberania popular e direitos humanos. O que se traduz, em uma segunda dimensão, na interdependência entre autonomia privada e pública. Na esteira dessas discussões, surge uma 
perspectiva jurídica procedimental, que vê no processo democrático o meio pelo qual é possível operacionalizar a interdependência entre os elementos outrora tidos como antagônicos: soberania popular e direitos humanos, autonomias privada e pública, utilizando-se de uma perspectiva procedimental discursiva sobre a construção do direito positivo.

De acordo com Habermas, para compreender adequadamente essa relação, faz-se necessário partir de uma perspectiva intersubjetivista, segundo a qual os direitos são derivados do próprio pertencimento a uma associação de jurisconsortes livres e iguais. Na mesma linha intersubjetivista de compreensão, esses direitos somente possuem legitimidade sob o reconhecimento recíproco das liberdades igualmente distribuídas; desse modo, esse caráter de reconhecimento integrativo atribui ao próprio direito uma força estruturadora. Mesmo possuindo uma lealdade procedimental, a solidariedade, elemento integrador próprio do mundo social, permanece como um recurso social do qual a autodeterminação democrática não pode desvincular-se, se pretende construir um direito legítimo².

Assim, o recurso efetivo às autonomias privada e pública, que se pressupõem mutuamente, é ao mesmo tempo uma condição para que os direitos civis sejam adequadamente interpretados e garantidos, além de utilizados de maneira cada vez mais abrangente em seu teor universalista. Pelo fato de que a reprodução do direito, considerada normativamente, sempre signifique a efetivação de uma associação de jurisconsortes livres e iguais, à qual todos os partícipes estão vinculados no respeito equânime de uns pelos outros, não surge nenhuma lacuna no processo circular da viabilização e asseguramento recíproco da autonomia privada e pública, ao menos não para uma autonomia social que devesse ser preenchida pela solidariedade dos partícipes de maneira diversa da que, aliás, já resulta do status próprio ao cidadão de um Estado. (HABERMAS, 2002, p. 384)

A relação de interdependência existente entre a soberania popular e o Estado de Direito reflete-se também na relação entre a autonomia dos cidadãos do Estado - autonomia pública - e a autonomia do cidadão da sociedade - autonomia privada -, uma vez que uma não consegue realizar-se sem a outra. Dado que a liberdade não pode ser

"Só são legítimas as regulamentações que tratam com igualdade o que é igual e com desigualdade o que é desigual, ou seja, as que também asseguram liberdades subjetivas de modo efetivo; e só se deve esperar regulamentação legítima como essas quando os cidadãos fazem uso de suas liberdades comunicativas em comum, de maneira que todas as vozes tenham iguais chances de ser ouvidas". (Habermas, 2002, p. 384) 
entendida como liberdade de arbítrio, o poder das leis também não pode ser tido como antecessor da vontade do soberano, assim também como não pode derivar da mesma, porque ele está contido no próprio processo de autolegislação política, assim como a autolegislação moral está contida no imperativo categórico, que reza que somente são aceitas aquelas máximas passíveis de generalização, isto é, que podem ser aceitas por todos, igualmente concebidos. Da mesma forma que a moral, o direito legítimo também protege a autonomia simétrica dos indivíduos; contudo, a positivação do direito requer uma divisão da autonomia, cisão esta que não se encontra no âmbito moral. O aspecto coercitivo das normas jurídicas não se estrutura sob os pressupostos do que é bom para todos, mas, sobretudo, nas decisões coercitivas generalizadas de instâncias criadoras e aplicadoras do direito. Donde se apresenta a necessidade de diferenciação entre autores que formam o direito e os destinatários desse mesmo direito. A autonomia que, no âmbito da moral, se constitui como uma estrutura unitária, apresenta-se no campo do direito sob dois aspectos: autonomia privada e pública.

No entanto, essa estrutura do direito pode apenas exigir daqueles aos quais esse direito está endereçado um comportamento em conformidade com as restrições legais, não adentrando o campo das motivações particulares. Portanto, não é possível o estabelecimento de exigências jurídicas pautadas no argumento do respeito às leis. Dessa forma, a autonomia privada somente pode ser assegurada através das liberdades subjetivas, que possibilitam e garantem uma estruturação autônoma da vida na medida em que não prescrevem qualquer ação, a não ser a compatibilidade necessária com as liberdades iguais de cada um. Portanto, a autonomia privada, dentro dessa roupagem, assume a figura da liberdade de arbítrio, garantida pelo sistema do direito.

É necessário, entretanto, não perder de vista que as pessoas do direito podem guiar suas ações a partir de um ponto de vista moral. Desse modo, para Habermas, todos devem ter a chance de seguir o direito também a partir do respeito às leis; essa necessidade requer do direito uma legitimação que transcenda a perspectiva abstrata do cidadão do Estado portador de direitos inalienáveis. "A razão prática, que se articula no 'poder das leis', liga-se, enquanto poder exercido legalmente, às características constitutivas do direito moderno". (HABERMAS, 2003a, p. 171) Isto somente é possível através de um processo de formação do direito marcado pela existência de um procedimento democrático da formação das opiniões e, também, da vontade de todos os 
possivelmente envolvidos, estrutura esta que fundamenta as suposições acerca da aceitabilidade racional dos resultados. "Aquilo que dá direito à participação política liga-se com a expectativa de um uso público da razão: como colegisladores democráticos, os cidadãos não podem fechar-se às exigências informais que resultam de uma orientação pelo bem comum". (HABERMAS, 2003a, p. 172)

A partir dessas considerações, pode parecer que a razão prática se encontraria ligada, se não exclusivamente, primordialmente à autonomia política, na medida em que ela parece ser o elemento responsável pela ligação dos cidadãos, enquanto autores e endereçados do direito. Entretanto, a razão prática realiza-se tanto no desenvolvimento da autonomia privada quanto da pública, pois, em ambos os casos, existem fins em si mesmos, e elas se constituem como meios para a realização uma da outra.

A exigência da orientação pelo bem comum, que se liga com a autonomia pública, constitui uma expectativa racional na medida em que somente o processo democrático garante que os "cidadãos da sociedade" cheguem simetricamente ao gozo de iguais liberdades subjetivas. Inversamente, somente uma autonomia privada dos "cidadãos da sociedade", assegurada, pode capacitar os "cidadãos do Estado" a fazer uso correto de sua autonomia política. A interdependência de democracia e Estado de Direito transparece na relação de complementaridade existente entre autonomia privada (cidadão da sociedade) e pública ou cidadã (cidadão do Estado): uma serve de fonte para a outra. (HABERMAS, 2003a, p. 173)

Para Habermas, o conceito procedimentalista, sob o qual seu paradigma está apoiado, não se confunde com os preceitos fundamentais contidos na figura do contrato. O conceito procedimentalista da teoria habermasiana ocorre do entrecruzamento do processo de consenso mútuo com outros de convenção, "bem como a ocorrência de procedimentos jurídicos e discursivos tais, que com eles só se garanta a justiça procedimental incompleta". (HABERMAS, 2002, p. 390)

As condições comunicativas, que possibilitam a livre circulação de informações e razões, permitem que se processem soluções de problemas e meios de aprendizagem sem, contudo, encontrar-se livre da dependência do encaminhamento de contribuições propriamente substanciais, já que as normas jurídicas não podem gerá-las espontaneamente. A posição habermasiana compreende que a garantia de liberdades subjetivas iguais é dependente do nível de clareza possível dos envolvidos, no que diz respeito a uma adequada interpretação das necessidades em questão e acerca dos pontos de 
vista relevantes, procedendo de tal forma que exerça ao mesmo tempo seu papel enquanto cidadão do Estado, utilizando-se para isso do uso público de suas liberdades comunicacionais, com o objetivo de construir um consenso racionalmente motivado 3 e processado democraticamente sobre as questões coletivamente importantes. "Essa concatenação interna (e recíproca) entre autonomia privada e pública, quando a entendemos corretamente, não é de forma alguma trivial, mas constitui, sim, o âmago normativo do paradigma procedimentalista". (HABERMAS, 2002, p. 391)

A prática comunicativa do uso público da razão, que permite a formação de consensos racionalmente motivados, elemento fundamental no processo de estruturação de uma Constituição democrática, permite uma ligação entre o exercício da soberania popular e a criação de um sistema de direitos. Nesse ponto, o autor parte do princípio segundo o qual devem buscar legitimidade exatamente aquelas regulamentações com as quais todos os possíveis atingidos poderiam, como participantes de discursos racionais, consentir enquanto norma legítima. Nos discursos, os agentes buscam construir visões comuns, enquanto nas negociações têm como objetivo uma equação de interesses.

A justeza destes acordos depende do procedimento fundamentado discursivamente na formação de compromissos, se as discussões constituem o local em que é formada a vontade política racional, a suposição de resultados legítimos, que funda-

Iris Marion Young faz uma importante crítica deste tipo de posição, considerando-a uma variante liberal da democracia deliberativa; para a autora, os teóricos deliberativistas deveriam rejeitar as posições que defendem pressupostos tais como: o princípio de que a deliberação é culturalmente neutra e universal; e que o processo de discussão que objetiva alcançar entendimento deve ou começar com a compreensão compartilhada ou acatar um bem comum como seu objetivo. Young argumenta que certos deliberativistas, ao tentarem sair do campo da defesa da imparcialidade, acabam por adentrar um terreno também ele problemático para a perspectiva deliberativista, a saber, da defesa da resolução de acordos pautados no bem comum. Em outras palavras, se as discussões partirem de uma noção de compreensão compartilhada ou aceitarem que o objetivo da deliberação seja o de alcançar um bem comum, então se deveria deixar pouco espaço para a dimensão transformadora das políticas deliberativas. Para resguardar a democracia deliberativa contra essa consequência conservadora, Young propõe ver as diferenças de cultura e perspectivas sociais como um recurso que enriquece a transformação do processo deliberativo, ao invés de algo que deva ser superado. Ela defende a concepção de democracia comunicativa (YOUNG, 1996), que reconhece a necessidade de uma concepção mais expansiva de comunicação política que não interprete os argumentos de uma forma culturalmente imparcial. Nem todas as culturas expressam a si mesmas num discurso que seja assertivo e confrontacional. Se o objetivo é assegurar que o processo democrático inclua essas outras pessoas e grupos, dever-se-á conceber a deliberação em outros moldes que não o confrontacional. Para Young, os democratas deliberativos como Gutmann, Thompson e Habermas têm como objetivo principal que os desacordos sejam resolvidos pela força do melhor argumento e não pela dependência econômica ou domínio político. Mas, se uma determinação da "força do melhor argumento" em si privilegia certas pessoas, então a inclusão no processo deliberativo é ameaçada. Para essa tendência de exclusão, Young sugere que os democratas deliberativos apoiem uma concepção ampliada de comunicação democrática. 
mentaram os procedimentos democráticos, tem de se apoiar em um procedimento comunicativo: As formas de comunicação necessárias para uma formação racional da vontade, portanto, garantidoras de legitimidade, do legislador político devem ser, por sua vez, institucionalizadas juridicamente. (HABERMAS, 2001, p. 148)

Habermas demonstra como ocorre essa ligação intrínseca entre direitos humanos e soberania popular, no interior de sua teoria, marcada por uma perspectiva intersubjetivista e dialógica. Os direitos humanos são os responsáveis pela institucionalização das condições de comunicação para a formação da vontade política racional, de sorte que não é possível que sua formação se dê por via externa ao próprio processo. 0 caminho traçado por esse raciocínio é evidente apenas sobre os direitos políticos de participação e comunicação, o mesmo não ocorrendo no que diz respeito aos direitos clássicos à liberdade, elemento garantidor da autonomia privada dos indivíduos; esses direitos contêm um valor intrínseco e não são absorvidos no campo de sua valoração instrumental para o processo de formação da vontade democrática. Para Habermas, não podemos deixar de tornar claro o meio pelo qual a autonomia política é exercida, ou seja, os cidadãos participam no processo legislativo apenas como sujeitos do direito, dentro da estrutura jurídica pré-existente.

Portanto, o código jurídico já deve encontrar-se como tal à disposição, antes que os pressupostos comunicativos para uma formação da vontade discursiva possam ser institucionalizados na figura de direitos civis. No entanto, para o estabelecimento desse código jurídico, é necessário, por sua vez, produzir o status das pessoas jurídicas individuais, que pertencem voluntariamente - como portadoras de direitos subjetivos - a uma associação de companheiros jurídicos e, em determinados casos, devem poder efetivamente reclamar os seus direitos à justiça. Não existe direito sem a autonomia privada das pessoas jurídicas individuais de um modo geral. Portanto, sem os direitos clássicos à liberdade, particularmente sem o direito fundamental às liberdades de ação subjetivas iguais, também não haveria um meio para a institucionalização jurídica daquelas condições sob as quais os cidadãos podem participar na práxis de autodeterminação. Desse modo, as autonomias privadas e públicas pressupõem-se reciprocamente. O nexo interno da democracia com o Estado de Direito consiste no fato de que, por um lado, os cidadãos só poderão utilizar condizentemente a sua autonomia pública se forem suficientemente independentes, graças a sua autonomia privada assegurada de modo igualitário. Por outro lado, só poderão usufruir de modo igualitário da autonomia privada, se eles, como cidadãos, fizerem um uso adequado de sua autonomia política. Por isso os direitos fundamentais liberais e políticos são indivisíveis. A imagem do núcleo e da casca é enganadora - como se existisse um âm- 
bito nuclear de direitos elementares à liberdade que devesse reivindicar precedência com relação aos direitos à comunicação e à participação. Para o tipo de legitimação ocidental, é essencial a mesma origem dos direitos à liberdade e civis. (HABERMAS, 2001, p. 148-149)

Em Direito e democracia, Habermas propôs que os fundamentos normativos do Estado Democrático de Direito fossem analisados como resultado de processos deliberativos e decisórios, com o intuito de criar uma associação autônoma de participantes do direito livres e iguais. Dentro desse objetivo, tal perspectiva procura responder da forma mais satisfatória possível à questão de quais os direitos necessários, reciprocamente, para possibilitar uma regulamentação legítima de nossa vida em sociedade, com os meios fornecidos pelo direito positivado. (cf. HABERMAS, 2003, p. 163) Partindo dessa posição e desses questionamentos, duas constatações merecem atenção: primeiramente, somente poderão ser consideradas legítimas as resoluções que podem ser consentidas por todos os possíveis participantes, sob as condições dos discursos racionais. (cf. HABERMAS, 1992, p. 142) ${ }^{4}$ Em segundo lugar, os participantes se comprometem, por meio de questionamentos direcionados, a considerar o direito moderno como meio para a regulamentação de sua convivência. Dessa maneira, a forma como a legitimação é construída, de um consenso geral, sob as bases de um discurso racional, e de um uso público da razão, assim como as noções de leis vinculativas que possibilitam um campo correspondente para as liberdades subjetivas, está em consonância com o conceito de autonomia política de Kant, segundo o qual "ninguém é livre, enquanto houver um único cidadão impedido de gozar de igual liberdade sob as leis que todos os cidadãos se deram a si mesmos, seguindo uma deliberação racional". (HABERMAS, 2003, p. 162)

Para compreender como a relação entre soberania popular e Estado de Direito não se constitui em uma relação paradoxal, mas sim de interdependência, é preciso entender como os direitos fundamentais, na sua generalidade, e não apenas os direitos políticos dos cidadãos, configuram-se como elementos constitutivos para a própria autolesgislação ${ }^{5}$. A teoria do discurso, bem como as teorias do contrato social têm como

"Isso não exclui, naturalmente, a possibilidade de falibilismo, pois a busca da única resposta correta não é capaz de garantir, por si mesma, um resultado correto. Somente o caráter discursivo do processo de deliberação é capaz de fundamentar a possibilidade de autocorreção reiterada e, destarte, a perspectiva de resultados racionalmente aceitáveis". (Habermas, 2003a, p. 162)

5 De acordo com Habermas: "É preciso ir ainda mais longe e demonstrar como os princípios democráticos são inerentes à constituição da democracia enquanto tal". (Habermas, 2003a, p. 167) 
base um Estado inicial que serve como ponto de partida; "neste Estado, pessoas em qualquer número resolvem entrar por si mesmas em uma prática constituinte". (Habermas, 2003, p. 168) Ou seja, a constituição, enquanto institucionalização das liberdades fundamentais, é o elemento inicial do processo de autolegislação democrática.

Essa ficção da liberdade de arbítrio cumpre plenamente o requisito, extremamente importante, da igualdade entre os participantes. Para além dessa condição primeira, apresentam-se certos requisitos funcionais, a saber: os cidadãos devem poder se reunir sob a mesma decisão de regular legitimamente sua convivência posterior por meio do direito positivo; em segundo lugar, precisam estar dispostos a participar dos discursos práticos, isto é, a preencher os requisitos pragmáticos que compõem uma ação argumentativa. Contudo, é importante salientar que essa suposição de racionalidade não se limita às considerações da racionalidade instrumental, como é o caso da tradição do direito natural moderno; da mesma forma, não se limita à moralidade, como em Kant e Rousseau, na medida em que apresenta como condição básica a razão comunicativa. Como última condição, é necessário que cada um esteja disposto a expressar o sentido de sua prática em um tema explícito, ou seja, primeiramente a prática tem como objetivo refletir sobre o sentido do projeto, e explicitá-lo em um segundo momento. "E essa reflexão é capaz de chamar a atenção para uma série de tarefas construtivas que têm que ser levadas a cabo antes do início concreto dos trabalhos constituintes". (HABERMAS, 2003a, p. 168)

Em Habermas, a gênese lógica dos direitos constitui-se no processo de aplicação do princípio do discurso aos direitos às liberdades subjetivas de ação, e se consagra na institucionalização da forma jurídica garantidora dos elementos necessários à prática discursiva da autonomia política, que possibilita equiparar a autonomia privada, outrora abstrata, com a forma jurídica. Desta forma, o próprio princípio de democracia somente pode ser entendido como o núcleo de um sistema de direitos. "A gênese lógica desses direitos forma um processo circular, no qual o código do direito e o mecanismo para a produção do direito legítimo, portanto, o princípio da democracia, se constituem de modo cooriginário". (HABERMAS, 1997, Tomo I, p. 158)

O conceito "forma jurídica", que estabiliza as expectativas sociais de comportamento do modo como foi dito, e do princípio do discurso, à luz do qual é possível examinar a legitimidade das normas de ação em geral, nos fornecem os meios 
suficientes para introduzir in abstrato as categorias de direitos que geram o próprio código jurídico, uma vez que determinam o status de pessoas de direito. (HABERMAS, 1997, Tomo I, p. 159)

Esse processo de construção de uma ordem jurídica legítima, tendo como medium o direito, precisa primeiramente construir uma ordem de status que prevê para todos os membros da futura associação o estatuto de portador de direitos subjetivos. Essa ordem de direitos positivos e obrigatórios somente pode realizar-se a partir da concretização de três categorias de direitos que requerem um assentimento geral como critério de legitimidade:

(a) direitos fundamentais (de conteúdo concreto variável), que resultam da configuração autônoma do direito, que prevê a maior medida possível de liberdades subjetivas de ação para cada um;

(b) direitos fundamentais (de conteúdo concreto variável), que resultam da configuração autônoma do status de membro de uma associação livre de parceiros do direito;

(c) direitos fundamentais (de conteúdo concreto variável), que resultam da configuração autônoma do igual direito de proteção individual, portanto, da reclamabilidade de direitos subjetivos. (HABERMAS, 2003a, p. 169)

Esses três componentes do direito são necessários para a fundamentação de uma associação de parceiros do direito que se reconhecem como portadores de diretos subjetivos reclamáveis. Tais categorias "nascem da aplicação do princípio do discurso ao médium do direito enquanto tal, isto é, às condições da formalização jurídica de uma socialização horizontal em geral". (HABERMAS, 1997, Tomo I, p. 159) Nesse plano, ocorre a antecipação do papel de cada indivíduo como destinatário do direito. Para que a autonomia das práticas desses cidadãos possa permanecer dentro desse processo, eles precisam transformar-se, via introdução de direitos fundamentais políticos, em legisladores políticos. Somente com a existência dessas três categorias de direitos fundamentais é possível conceber a existência do próprio direito. Entretanto, sem uma configuração política de tais categorias, o próprio direito não seria capaz de adquirir conteúdos concretos; portanto, apresenta-se como essencial a introdução de uma quarta categoria de direitos, a saber: "(d) Direitos fundamentais (de conteúdo concreto variável), que resultam da configuração autônoma do direito para uma participação, em igualdade de 
condições, na legislação política". (HABERMAS, 2003a, p. 169) Tendo em vista que os direitos políticos criam o status de cidadãos livres e iguais, e que estes possibilitam a mudança da posição dos civis perante os direitos, com o intuito da interpretação e da configuração da autonomia privada e pública, os direitos apresentados até agora implicam um quinto tipo de direito: "(e) Direitos fundamentais a condições de vida garantidas social, técnica e ecologicamente, na medida em que isso for necessário para um aproveitamento, em igualdade de chances, dos direitos elencados de (1) a (4)". (HABERMAS, 1997, Tomo I, p. 160)

Habermas salienta que esse cenário, destinado a cristalizar-se numa prática deliberativa, ocorre num plano conceitual, pois, antes de determinar o primeiro ato de criação do direito, é preciso obter clareza sobre o empreendimento adotado. A partir do momento em que se torna explícito o sentido performativo dessa prática, os indivíduos compreendem a necessidade de criar ao mesmo tempo as quatro categorias de direitos fundamentais. É claro que esses direitos não podem ser construídos abstratamente; portanto, precisam ultrapassar o plano da reflexão conceitual para captar, no plano empírico, aquelas matérias que necessitam de regulamentação. Nesse ponto das discussões, é necessário fazer uma distinção muito importante entre dois níveis: 1) o nível da explicação da linguagem dos direitos subjetivos, ou seja, no plano de sua validade; e 2) o nível da efetivação desse princípio, através de sua realização prática, em suma, no campo da facticidade desse processo.

Tão logo a prática da autodeterminação cidadã for entendida como um processo longo e ininterrupto de realização e de configuração do sistema de direitos fundamentais, o princípio da soberania popular emergirá por si mesmo na ideia do Estado de Direito. Esse cenário da gênese conceitual dos direitos fundamentais, distribuído em dois níveis, revela plasticamente que os passos conceituais preparatórios explicitam exigências que, necessariamente, são colocadas a uma autolesgislação democrática que se estrutura pelo caminho do direito. Longe de constituírem barreiras à prática, estas exigências não fazem mais do que explicitá-las. Neste contexto, o princípio democrático somente pode ser concretizado juntamente com a ideia do Estado de Direito, pois ambos os princípios encontram-se numa relação de implicação material recíproca. (HABERMAS, 2002, p. 171) 


\section{O conceito de democracia deliberativa em Habermas}

O princípio do discurso (D) consiste num princípio normativo neutro em relação à moral e ao direito, de modo que, para a moral, assume a forma de um princípio de universalização - princípio (U) - para testar a possibilidade de aceitação de uma norma; e assume, para o direito, a forma de um princípio de democracia - princípio (De) - para a legitimação de normas jurídicas.

O princípio da democracia pressupõe a possibilidade da decisão racional de questões práticas em geral, mais precisamente, refere-se à legitimação daquelas normas de ação que surgem sob a forma do direito. O princípio da democracia enquanto tal não é uma regra da argumentação, ele nada diz sobre se e como é possível abordar discursivamente questões prático-morais: refere-se às condições abstratas de institucionalização da formação racional da opinião e da vontade, através de um sistema de direitos que garante a cada um igual participação no processo de normatização jurídica. (WERLE, 2009, p. 280)

O processo circular de formação dos direitos estrutura uma relação de interdependência entre o código do direito (forma jurídica) e o mecanismo para a produção do direito legítimo vertido em princípio do discurso; partindo-se deste entrelaçamento, o princípio (D) assume, pela via da institucionalização jurídica, a figura do princípio de democracia, o qual confere força legitimadora ao processo de normatização. Na medida em que o sistema de direitos assegura tanto a autonomia privada quanto a pública, ele operacionaliza a tensão entre a facticidade (positividade) e a validade (legitimidade) do direito, estes momentos se unem no cruzamento entre forma do direito e princípio do discurso, inclusive na dupla face de Janus que o direito volve: de um lado, para seus destinatários e, de outro, para seus autores. Aqui parece repousar uma nova tensão entre facticidade e validade, resultado da circunstância, à primeira vista, paradoxal "de que os direitos políticos fundamentais têm que institucionalizar o uso público das liberdades comunicativas na forma de direitos subjetivos". (HABERMAS, 1997, Tomo I, p. 167) De acordo com Habermas, o código do direito não abre outra escolha, os direitos relacionados à liberdade comunicativa necessitam ser formulados em uma linguagem que dê margem à escolha dos sujeitos do direito na utilização ou não de suas liberdades comunicativas. O surgimento da legitimidade através da legalidade não é paradoxal, a 
não ser se partirmos de uma perspectiva circular na qual o sistema de direitos legitima-se a si mesmo.

A compreensão discursiva do sistema dos direitos conduz o olhar para dois lados: de um lado, a carga da legitimação da normatização jurídica das qualificações dos cidadãos desloca-se para os procedimentos da formação discursiva da opinião e da vontade, institucionalizados juridicamente. De outro lado, a juridificação da liberdade comunicativa significa também que o direito é levado a explorar fontes de legitimação das quais não pode dispor. (HABERMAS, 1997, Tomo I, p. 168)

Os direitos fundamentais são constitutivos para toda associação de membros jurídicos livres e iguais. Neste direito se reflete uma socialização horizontal dos civis; contudo, tal ato de institucionalização jurídica da autonomia política é incompleto em determinados pontos, o que impede que esta possa estabilizar-se a si mesma. Para que possa tornar-se real o entrelaçamento entre autonomia privada e pública, é preciso que o processo de juridificação não se encontre limitado às liberdades subjetivas das pessoas privadas, assim como às liberdades comunicativas do cidadão. No interior de uma concepção discursiva da democracia, o poder político é entendido como um processo permeado por negociações e processos argumentativos. Desta forma, a criação legítima do direito depende de certo número de condições exigentes que só podem ser implementadas e examinadas através de processos comunicativos nos quais a razão assume uma figura procedimental. De acordo com Habermas, "uma sociologia reconstrutiva da democracia tem que escolher seus conceitos básicos de tal modo que estes permitam identificar nas práticas políticas fragmentos de uma "razão existente", mesmo que distorcida". (HABERMAS, 1997, Tomo II, p. 9)

Em suma, a jurificação deve estender-se simultaneamente ao poder político pressuposto como médium do direito -, do qual depende a obrigatoriedade da normatização, e à implementação do direito. Desta constituição cooriginária e da interligação entre direito e poder político surge uma segunda necessidade de legitimação; ou seja, o exercício deste pelo executivo necessita, ele também, de processos de legitimação. Será sobre esta estrutura que repousa o conceito de Estado Democrático de Direito.

Na reconstrução do vínculo interno entre Estado de Direito e democracia deliberativa, apresentada no nível de socialização horizontal da autodeterminação dos cidadãos, o argumento de Habermas consiste em ressaltar o sentido intersubjetivo 
dos direitos da cidadania democrática: são relações que têm sua base nas estruturas de reconhecimento recíproco, têm os mesmos pressupostos da racionalidade comunicativa. Os pressupostos quasi-transcendentais das experiências de reconhecimento recíproco, vivenciadas no face a face da vida quotidiana e na forma reflexiva do discurso, estão incorporados no próprio sistema moderno de direitos, que possibilita diferentes experiências de respeito e reconhecimento recíprocos entre indivíduos estranhos entre si, e que querem permanecer estranhos. (WERLE, 2008, p. 284)

Com a teoria do discurso, uma nova perspectiva entre em cena: procedimento e pressupostos comunicacionais da formação democrática da opinião e da vontade funcionam como importantes escoadouros da racionalização discursiva das decisões de um governo e administração vinculados ao direito e à lei. Racionalização significa mais do que mera legitimação, mais mesmo do que a própria ação de constituir o poder. 0 poder administrativamente disponível modifica seu estado de mero agregado, desde que seja retroalimentado por uma formação democrática da opinião e da vontade que não apenas exerce posteriormente o controle do exercício do poder político, mas que também o programe, de uma maneira ou de outra. A despeito disso, o poder político só pode "agir". Ele é um sistema parcial especializado em decisões coletivas vinculativas, ao passo que as estruturas comunicativas da opinião pública compõem uma rede amplamente disseminada de sensores que reagem à pressão das situações problemáticas do todo social e que simulam opiniões influentes. A opinião pública transformada em poder comunicativo segundo procedimentos democráticos não pode "dominar", mas apenas direcionar o uso do poder administrativo para determinados canais ${ }^{6}$.

6 Tem-se debatido muito, no interior das teorias democráticas, sobre a institucionalização da participação social no processo de definição de agendas públicas e da normatização do direito. No interior destas discussões, a teoria de Habermas tem recebido diversas críticas. Para Avritzer (AVRITZER, 2000, p. 40), cuja posição ilustra bem a crítica de inúmeros autores a Habermas, existe uma contradição no interior da teoria de Habermas: de um lado, o conceito de deliberação funda todo o processo de legitimação dos direitos políticos, na medida em que o poder administrativo não possui a capacidade de gerar legitimidade. De outro lado, ele não é capaz de produzir arranjos institucionais, porque a sua forma não supõe nada mais que a influência em relação ao sistema político. Desta maneira, o autor deixa de dar um formato institucional à democracia deliberativa: de acordo com Habermas, a institucionalização destes espaços tem como consequência um rompimento com a dinamicidade social que the era presente devido mesmo ao seu formato fluido e não burocrático. Para Habermas, institucionalizar os espaços de interação intersubjetiva do mundo da vida significa uma colonização sistêmica destes espaços pelas lógicas do poder e do dinheiro. Dentro destas discussões acerca da institucionalização ou não dos espaços participativos, Joshua Cohen defende que, "porque os membros de uma associação democrática consideram os procedimentos deliberativos a fonte da legitimidade... eles preferem instituições nas quais as conexões entre deliberação e resultados sejam mais evidentes do que instituições nas quais tais conexões sejam menos claras". (COHEN, 1989, p. 73) A tentativa teórica de Cohen consiste na transformação do processo de discussão argumentativa proposto por Habermas em um processo de deliberação institucional. Seu objetivo é, portanto, o de transformar 
$\mathrm{Na}$ teoria do discurso, o desabrochar da política deliberativa não depende de uma cidadania capaz de agir coletivamente e, sim, da institucionalização dos correspondentes processos e pressupostos comunicacionais, como também do jogo entre deliberações institucionalizadas e opiniões públicas que se formam de modo informal. (HABERMAS, 1997, Tomo II, p. 21)

O conceito de soberania popular deve-se à apropriação republicana e à revalorização da noção de soberania surgida no início da era moderna e inicialmente associada aos déspotas que governavam de modo absolutista. O Estado, que monopoliza os meios da aplicação legítima da força, é concebido como um concentrado de poder, capaz de prevalecer sobre todos os demais poderes do mundo. Rousseau transpôs essa figura de pensamento (proposta inicialmente por Bodin) à vontade do povo unificado, mesclada à ideia clássica do autodomínio de indivíduos livres e iguais e suprassumida no conceito moderno de autonomia. Apesar dessa sublimação normativa, o conceito de soberania permaneceu ligado à noção de uma corporificação sua no povo. Segundo a concepção republicana, o povo (ao menos potencialmente presente) é portador de uma soberania que por princípio não se pode delegar: não é admissível que, em sua qualidade de soberano, o povo se deixe representar. A isso o liberalismo contrapõe a concepção mais realista de que no Estado Democrático de Direito o poder estatal que nasce do povo só é exercido "em eleições e votações e por meio de organismos legislativos específicos, organismos do poder executivo e da jurisdição".

Ao conceito de discurso na democracia corresponde a imagem de uma sociedade descentralizada, que na verdade diferencia e autonomiza com a opinião pública um cenário propício à constatação, identificação e tratamento de problemas pertinentes à sociedade como um todo. Quando se sacrifica a formação de conceito ligada à filosofia do sujeito, a soberania não precisa concentrar-se no povo de forma concretista, nem se exilar na anonimidade de competências atribuídas pelo direito constitucional. O si-mesmo da comunicação jurídica que se organiza desaparece em formas de comunicação isentas de sujeitos, as quais regulam o fluxo da formação discursiva das opiniões e vontades, de modo que seus resultados falíveis guardem para si a suposição

o consenso sobreposto e hipotético numa forma de operação das instituições políticas, dentro de uma situação de pluralismo. Diferentemente de Habermas, Cohen defende que pode haver decisões que não ocorram por consenso e que, ainda assim, sejam legítimas. O argumento utilizado é o de que, se o processo de decisão, ainda que por maioria, for um processo inclusivo e pautado na troca de razões, tal processo será aceito pela maioria enquanto legítimo. (COHEN 1989, p. 73) 
de racionalidade. Com isso, a intuição vinculada à ideia de soberania popular não é desmentida, mas interpretada de maneira intersubjetiva. Uma soberania popular, mesmo que se tenha tornado anônima, só se abriga no processo democrático e na implementação jurídica de seus pressupostos comunicacionais, bastante exigentes por sinal, caso tenha por finalidade conferir validação a si mesma como poder gerado por via comunicativa. Mais exatamente, essa validação provém das interações entre a formação da vontade institucionalizada de maneira jurídico-estatal e as opiniões públicas culturalmente mobilizadas, que de sua parte encontram uma base nas associações de uma sociedade civil igualmente distante do Estado e da economia.

A autocompreensão normativa da democracia exige para a comunidade jurídica um modo de coletivização social; esse mesmo modo de coletivização social, porém, não se estabelece para o todo da sociedade em que se aloja o sistema político constituído de maneira jurídico-estatal. Também em sua autocompreensão, a política deliberativa continua sendo elemento constitutivo de uma sociedade complexa que no todo se exime de assumir um ponto de vista normativo como o da teoria do direito. Nesse sentido, a leitura da democracia, a partir da teoria do discurso, vincula-se a uma abordagem distanciada para a qual o sistema político não é nem o topo nem o centro da sociedade, nem muito menos o modelo que determina sua marca estrutural, mas sim um sistema de ação ao lado dos outros.

Em todo caso, esse modelo de democracia não precisa mais operar com o conceito de uma totalidade social centrada no Estado, representado como um sujeito superdimensionado e agindo em função de um objetivo. Ele também não representa a totalidade num sistema de normas constitucionais que regulam de modo neutro o equilíbrio do poder e dos interesses segundo o modelo do mercado. Pois, a teoria do discurso dispensa os clichês da filosofia da consciência que recomendam que atribuamos, de um lado, a prática de autodeterminação dos sujeitos privados a um sujeito da sociedade tomada como um todo, e, de outro lado, que imputemos a dominação anônima das leis a sujeitos particulares que concorrem entre si. (HABERMAS, 1997, Tomo II, p. 21)

Como a política consiste em uma espécie de lastro reserva na solução de problemas que ameacem a integração, ela certamente tem de poder se comunicar pelo médium do direito com todos os demais campos de ação legitimamente ordenados, seja qual for a maneira como eles se estruturem ou direcionem. Se o sistema político, no entanto, depende de outros desempenhos do sistema, isso não se dá em um sentido 
meramente trivial; ao contrário, a política deliberativa, realizada ou em conformidade com os procedimentos convencionais da formação institucionalizada da opinião e da vontade, ou informalmente, nas redes da opinião pública, mantém uma relação interna com os contextos de um universo de vida cooperativo e racionalizado. Justamente os processos comunicativos de cunho político que passam pelo filtro deliberativo dependem de recursos do universo vital - da cultura política libertadora, de uma socialização política esclarecida e, sobretudo, das iniciativas das associações formadoras de opinião -, recursos que se formam de maneira espontânea ou que, em todo caso, só podem ser atingidos com grande dificuldade, caso o caminho escolhido para se tentar alcançá-los seja o do direcionamento político.

A teoria do discurso conta com a intersubjetividade de processos de entendimento, situada num nível superior, os quais se realizam através de procedimentos democráticos ou na rede comunicacional de esferas públicas políticas. Essas comunicações destituídas de sujeitos - que acontecem dentro e fora do complexo parlamentar e de suas corporações - formam arenas da opinião e da vontade acerca de matérias relevantes para toda a sociedade e necessitadas de regulamentação. (HABERMAS, 1997, Tomo II, p. 22)

A reconstrução do espaço público dentro de uma perspectiva emancipatória se dá, segundo Habermas, contemplando procedimentos racionais, discursivos, participativos e pluralistas, que permitam aos atores da sociedade civil um consenso comunicativo e uma autorregulação, fonte de legitimidade das leis, entendendo que nem o espaço doméstico nem o da produção contêm esse potencial. A autonomia do espaço público participativo revaloriza o primado da comunidade e da solidariedade, possibilitando a libertação da sociedade civil dos imperativos sistêmicos, isto é, dos controles burocráticos do Estado e das imposições econômicas do mercado. Portanto, o espaço público não é um espaço de neutralidade que está dissociado dos interesses concretos dos atores sociais, mas propicia a institucionalização da pluralidade e a possibilidade do consenso, por meio de procedimentos comunicativos exercidos na esfera pública, fornecendo os critérios éticos de regulação dos discursos práticos. A esfera pública, por fim, é a instância geradora de decisões coletivas e legitimadoras da democracia. Para compreender esse papel desempenhado pela esfera pública, é imperioso compreender como Habermas edificou tal conceito. 
Esta estrutura teórica é sustentada por uma ideia de deliberação argumentativa, que atribui à esfera pública o papel de tornar-se o local da deliberação comunicativa, onde as diversas concepções se colocam em contato, proporcionando uma rede de procedimentos comunicativos que se aproximam da realização do princípio democrático. A deliberação democrática envolveria "uma soberania popular procedimentalizada e um sistema político ligado a redes periféricas de uma esfera pública política". (HABERMAS, 1994, p. 7)

O fluxo comunicacional que serpeia entre formação pública da vontade, decisões institucionalizadas e deliberações legítimas, garante a transformação do poder produzido comunicativamente, e da influência adquirida através da publicidade, em poder aplicável administrativamente pelo caminho da legislação. (HABERMAS, 1997, Tomo II, p. 22)

A partir de tais colocações, fica clara a ambivalência estrutural da própria esfera pública, tal qual concebida por Habermas, correspondente ao seu grau de deliberação e de poder decisório: de um lado, encontramos a esfera pública geral, caracterizada pelo debate público de problemas; por outro lado, há a esfera pública procedimentalmente regulada, na qual reside o papel efetivamente decisório; ou seja, nela repousa o sistema político, que é o responsável pelas decisões que refletem os interesses e influências da esfera pública geral ou dos locais de discussão extrainstitucional. Enquanto antigamente a natureza pública das negociações e atividades devia assegurar a todos a continuidade entre a discussão pré-parlamentar e a discussão parlamentar, garantindo a unidade da esfera pública e da opinião pública que aí se constituía, hoje, em virtude de sua alteração estrutural, ela só pode exercer uma função crítica quando se sujeita ao uso público da razão?.

Nas palavras de Habermas:

A formação da opinião, desatrelada das decisões, realiza-se em uma rede pública e inclusiva de esferas públicas subculturais que se sobrepõem uma às outras, cujas fronteiras reais, sociais e temporais são fluidas. As estruturas de tal esfera pública plu-

[...] o parlamento deliberativo [era visto] como meio, mas também como parte do público, hoje ela não faz nada semelhante; ela nem sequer o pode, pois a própria esfera pública, tanto dentro como fora do parlamento, alterou sua estrutura... A esfera pública só pode exercer sua função de crítica política e de controle à medida que, além da cogestão de compromissos políticos, está ela mesma sujeita, sem limitações, às condições de coisa pública e da publicidade. (HABERMAS, 2003a, p. 241-44) 
ralista formam-se de modo mais ou menos espontâneo, num quadro garantido pelos direitos humanos. E através da esfera pública que se organiza no interior de associações, movimentam-se os fluxos comunicacionais, em princípio ilimitados, formando os componentes informais da esfera pública geral. Tomados em sua totalidade, eles formam um complexo "selvagem" que não se deixa organizar completamente. Devido à sua estrutura anárquica, a esfera pública geral está muito mais exposta aos efeitos de repressão e de exclusão do poder estatal - distribuído desigualmente -, da violência estrutural e da comunicação sistematicamente distorcida, do que as esferas públicas organizadas do complexo parlamentar, que são reguladas por processos. De outro lado, porém, ela tem a vantagem de ser um meio de comunicação isento de limitações, no qual é possível captar melhor novos problemas, conduzir discursos expressivos de autoentendimento e articular, de modo mais livre, identidades coletivas e interpretações de necessidade. A formação democrática da opinião e da vontade depende de opiniões públicas informais que idealmente se formam em estruturas de uma esfera pública política não desvirtuada pelo poder. De sua parte, a esfera pública precisa contar com uma base social na qual os direitos iguais do cidadão conseguiriam eficácia social. (HABERMAS, 1997, p. 32)

A esfera pública constitui-se como a arena de formação da vontade coletiva, espaço do debate público e do embate dos diversos atores da sociedade. Esse espaço público autônomo apresenta uma dimensão dupla: desenvolve processos de formação democrática da opinião pública e da vontade política coletiva, e se vincula a um projeto de ação democrática efetiva, em que a sociedade civil se torna uma instância deliberativa e legitimadora do poder político, na qual os cidadãos são capazes de exercer seus direitos subjetivos públicos.

Dessa compreensão da democracia resulta a exigência normativa de um deslocamento de pesos nas relações entre dinheiro, poder administrativo e solidariedade, a partir das quais as sociedades modernas satisfazem suas necessidades de integração e de regulação. Aqui as implicações normativas são evidentes: a força social e integradora da solidariedade, que não pode ser extraída apenas de fontes do agir comunicativo, deve desenvolver-se através de um amplo leque de esferas públicas autônomas e de processos de formação democrática da opinião e da vontade, institucionalizados através de uma constituição, e atingir os outros mecanismos de integração social - o dinheiro e o poder administrativo - através do médium do direito. (HABERMAS, 1997, Tomo II, p. 22)

Portanto, o espaço público é visto como uma esfera de discurso, autônoma em relação ao sistema político, como o local onde se realiza a interação intersubjetiva de 
cidadãos conscientes, solidários e participativos, assim como também é o espaço da interação entre os subsistemas sociais. Assim, a valorização do conceito de cidadania propiciou a revalorização das práticas sociais, levando a participação política a ultrapassar o mero ato de votar.

Nesse raciocínio, a política transcende os interesses privados: nesse ponto, Habermas se distingue dos liberais por conferir centralidade à ação social, tornando secundários os aspectos individuais. O espaço público não se constitui em um espaço de neutralidade que está dissociado dos interesses concretos dos atores sociais, embora permita a institucionalização da $^{8}$ e a possibilidade do consenso por meio de procedimentos comunicativos exercidos na esfera pública, fornecendo os critérios éticos de regulação dos discursos práticos.

Nesse sentido, a esfera pública é a instância geradora de decisões coletiva e legitimadora da democracia. Habermas também se distingue dos pensadores republicanos, na medida em que unifica a ação na esfera comunicativa procedimental, e não nos valores cívicos. No espaço público serão desenvolvidos debates públicos em torno dos interesses coletivos, possibilitando uma ação comum a partir do princípio do discurso. Habermas compartilha com os liberais a ideia de que a legitimidade deriva do embate público. Contudo, para o autor, esse debate não pressupõe o constrangimento da neutralidade: sendo julgado por critérios de um modelo de discurso prático, a esfera pública só é possível quando todos os indivíduos afetados empreendem um discurso prático, avaliando suas pretensões de validade.

Dessa forma, a noção de esfera pública politicamente ativa precisa ser reavaliada, na medida em que Estado e sociedade se interpenetram mutuamente e que, portanto,

8 Uma questão muito debatida pelos interlocutores de Habermas é o papel ocupado pela imparcialidade na teoria habermasiana. De acordo com esta perspectiva, o raciocínio imparcialista é um argumento desenvolvido para retirar o foco das discussões do campo das relações de poder, ou seja, a imparcialidade argumentativa constitui-se no elemento possibilitador de discussões racionalmente motivadas e que direcionam a discussão deliberativa para um consenso racionalmente motivado a partir da força dos melhores argumentos. Uma vez que os pressupostos da racionalidade comunicativa constituem o pano de fundo possibilitador das posições imparciais, fruto do uso público da razão orientada ao consenso motivado racionalmente. Contudo, este raciocínio imparcialista tem sido fortemente criticado devido a seu grau de abstração e de autolimitação no que tange à concepção de quais são os melhores argumentos. Rejeita-se fortemente a argumentação de que a deliberação, sob as condições certas - livre de coerção e relações de poder -, seja o elemento central na constituição da legitimidade das leis e políticas públicas. O elemento neufrágico não é uma avaliação das possibilidades de uma deliberação em condições inatingíveis que seguem regras argumentativas muito abstratas, mas uma melhor compreensão da natureza e significado da deliberação sob condições "não ideais". (cf. FARRELY, 2004) 
estarão presentes, no interior do Estado, interesses privados organizados coletivamente, visto que estes precisam afirmar sua autonomia privada, por meio de uma autonomia política, no interior da esfera pública. Tais organizações fazem uso da publicidade de tipo demonstrativo. Dessa maneira, torna-se necessária uma reestruturação da esfera pública para que esta possa exercer sua função crítica.

Desse modo, a reconstrução do espaço público ocorre, segundo Habermas, dentro de uma perspectiva emancipatória, quando se contemplam procedimentos racionais, discursivos, participativos e pluralistas que permitam aos atores da sociedade civil um consenso comunicativo e uma autorregulação, fonte da legitimidade das leis. Nem o espaço doméstico nem o da produção contêm esse potencial.

A autonomia do espaço público participativo revaloriza o primado da comunidade e da solidariedade, possibilitando a libertação da sociedade civil dos controles burocráticos do Estado e das imposições do mercado. Disto deriva que o espaço público é entendido democraticamente como o lócus da criação de procedimentos sociopolíticos, de cuja formulação e adoção podem participar todos os afetados por normas sociais gerais e decisões políticas coletivas.

O modelo discursivo parece adequado às sociedades modernas, pois, com o ingresso de novos grupos na esfera pública e a expansão dos direitos de cidadania na modernidade, não é mais possível imaginar um espaço público homogêneo e politicamente igualitário. O modelo habermasiano amplia a esfera da atividade política, fecundando-a com os influxos comunicativos provenientes da sociedade civil; nesse modelo, as bases normativas da democracia estão em uma teoria da razão pós-metafísica, ou seja, na teoria da ação comunicativa e, de forma mais latente, na noção de discurso enquanto forma reflexiva desse tipo de ação.

Para Habermas, apesar da importância do papel desempenhado pelos discursos de autoentendimento mútuo, em especial no que tange ao sentido de integração social, no interior de sociedades pluralistas - cultural e socialmente -, existem ações voltadas aos interesses e orientações de valor. Portanto, a justiça e a honestidade dos acordos se medem pelos pressupostos e procedimentos que precisam, eles mesmos, de uma justificação racional e até mesmo normativa sob o ponto de vista da justiça. Diversamente do que se dá com questões éticas, as questões de justiça não estão relacionadas desde a origem a uma comunidade em particular. O direito firmado politicamente, caso 
se pretenda legítimo, precisa ao menos estar em consonância com princípios morais que reivindiquem validação geral, para além de uma comunidade jurídica concreta (cf. Habermas, 2003, p. 285)

Dessa forma, o conceito de política deliberativa só pode ter referência empírica quando é delimitado à diversidade de estruturas comunicativas, na qual se forma uma vontade comum: não apenas por um autoentendimento de caráter ético, mas também pela busca de equilíbrio entre interesses divergentes e estabelecimento de acordos, checagem da coerência jurídica, escolha de instrumentos racionais, e voltada a um fim específico, e por meio, enfim, de uma fundamentação moral. Dessa forma, os modelos apresentados como uma forma de tipologia ideal podem impregnar-se e complementar-se. A política dialógica e a instrumental, quando as formas de comunicação estão respectivamente institucionalizadas, podem entrecruzar-se no médium das deliberações. Tudo depende, portanto, das condições de comunicação e procedimento que conferem força legitimadora à formação institucionalizada da opinião e da vontade. O modelo de democracia sugerido por Habermas baseia-se nas condições de comunicação, sob as quais o processo político supõe-se capaz de alcançar resultados racionais, justamente por cumprir-se em todo o seu alcance, de modo deliberativo. Quando o cerne da teoria democrática passa a ser o conceito procedimental de política deliberativa, tem-se como resultado um modelo diferente tanto da posição liberal do Estado como defensor da sociedade econômica quanto da republicana, que vê o Estado como uma comunidade ética.

A teoria do discurso acolhe elementos de ambos os lados e os integra no conceito de um procedimento ideal para o aconselhamento e tomada de decisões. Esse procedimento democrático cria uma coesão interna entre negociações, discursos de autoentendimento e discursos sobre a justiça, além de fundamentar a suposição de que, sob tais condições, se almejam resultados ora racionais, ora justos e honestos. Com isso, a razão prática desloca-se dos direitos universais do homem ou da eticidade concreta de determinada comunidade e restringe-se a regras discursivas e formas argumentativas da ação que se orientam ao estabelecimento de um acordo mútuo, isto é, da estrutura da comunicação linguística, permitindo uma articulação entre os conceitos de Estado de Direito e soberania popular, considerados, até o momento, dicotômicos. 


\section{Bibliografia}

FREITAG, Bárbara. 1990. A Teoria Crítica ontem e hoje. São Paulo: Edição Brasiliense.

HABERMAS, Jürgen. 1987a. "A nova intransparência - A crise do Estado de bem-estar social e o esgotamento das energias utópicas". Novos Estudos CEBRAP, São Paulo, n. 18, p. 103-114. 1987b. "Conhecimento e interesse". In: . Técnica e ciência como "ideologia". Lisboa: Edições 70. 1987. Teoria de la acción comunicativa. Madrid: Taurus, 1987c. Tomo I e II. 1989a. Consciência moral e agir comunicativo, Rio de Janeiro: Tempo Brasileiro. 1989b. "Para o uso pragmático, ético e moral da razão prática", São Paulo, Revista Estudos Avançados.

1989. Teoria de la acción comunicativa: complementos y estúdios prévios. Madrid: Cátedra. 1990. Pensamento pós-metafísico. Rio de Janeiro: Tempo Brasileiro. 1995. "Três modelos normativos de democracia", Lua Nova, Revista de Cultura e Política, n. 36, p. 39-53.

1997. Direito e democracia: entre facticidade e validade. Rio de Janeiro: Tempo Brasileiro.

2000. O discurso filosófico da modernidade. São Paulo: Martins Fontes. 2001. A constelação Pós-Nacional: Ensaios políticos. São Paulo: Littera Mundi. 2003a. Era das transições. Rio de Janeiro: Tempo Brasileiro. 2003b. Mudança estrutural da esfera pública. Rio de Janeiro: Tempo Brasileiro. 2002. A inclusão do outro: estudos em Teoria Política. São Paulo: Loyola. 2004. A ética da discussão e a questão da verdade, São Paulo: Martins Fontes.

WERLE, Denilson. 2008. Justiça e democracia: ensaios sobre John Rawls e Jürgen Habermas. São Paulo: Singular; Esfera Pública, 2008.

2009. "Pluralismo e tolerância. Sobre o uso público da razão em Habermas". In: . O pensamento vivo de Habermas: uma visão interdisciplinar. Alessandro Pinzani, Clóvis M. de Lima, Delamar V. Dutra (Coord.). Florianópolis: NEFIPO.

Recebido: 05/04/2014

Aceito: 27/07/2014 